\title{
HUBUNGAN ANTARA PEMBERIAN ASI EKSKLUSIF DENGAN PERKEMBANGAN BAHASA ANAK USIA 12-36 BULAN DI PUSKESMAS TAMAMAUNG MAKASSAR
}

\author{
Rahayu Soamole $^{1)}$, Wa Ode Sri Asnaniar ${ }^{2)}$, Yusrah Taqiyah ${ }^{3)}$, Suchi Avnalurini Sharief ${ }^{4)}$ \\ ${ }^{1,2,3}$ Program Studi Ilmu Keperawatan, Universitas Muslim Indonesia \\ ${ }^{4}$ Program Studi DIII Kebidanan, Universitas Muslim Indonesia \\ E-mail: Ayusoamole87@gmail.com ${ }^{1)}$,waode.sriasnaniar@umi.ac.id ${ }^{2)}$, yusrah.taqiyah@yahoo.co.id ${ }^{3)}$ \\ suchiavnalurini.shariff@umi.ac.id ${ }^{4)}$
}

\begin{abstract}
ABSTRAK
ASI eksklusif adalah menyusui bayi secara murni dimana bayi hanya diberi ASI saja selama 6 bulan tanpa tambahan cairan ataupun makanan lain. Manfaat-manfaat dari menyusui telah di dokumentasikan diseluruh dunia, namun hanya 39\% anak-anak dibawah 6 bulan mendapat ASI eksklusif. Tujuan penelitian ini untuk mengetahui hubungan antara pemberian ASI eksklusif dengan perkembangan bahasa anak usia 12-36 bulan di Wilayah Kerja Puskesmas Tamamaung Makassar.

Desain penelitian yang digunakan adalah survey analitik dengan pendekatan cross sectional study. Penelitian ini menggunakan purposive sampling dengan besar sampel sebanyak 40 responden. Uji hubungan dilakukan dengan menggunakan uji statistik Chi-Square dengan tingkat kemaknaan $\alpha=<$ 0,05. Hasil penelitian menunjukkan bahwa ada hubungan antara pemberian ASI eksklusif dengan perkembangan bahasa anak di Wilayah kerja Puskesmas Tamamaung Makassar $(\rho=0,021)$. Berdasarkan hasil penelitian, menunjukkan bahwa ada hubungan antara pemberian ASI eksklusif dengan perkembangan bahasa anak di Wilayah Kerja Puskesma Tamamaung Makassar. Untuk itu, disarankan kepada pihak terkait untuk memberikan penyuluhan intensif kepada ibu-ibu terutama kepada ibu-ibu muda yang mempunyai anak tentang pentingnya pemberian ASI eksklusif bagi pertumbuhan dan perkembangan anak.
\end{abstract}

Kata Kunci : ASI, Perkembangan Bahasa, Balita.

\begin{abstract}
Exclusive breastfeeding is breastfeeding a pure baby, where the baby is only given breast milk for 6 months without additional fluids or other foods. The benefits of breastfeeding have been documented worldwide, but only 39\% of children under 6 months get exclusive breastfeeding. The purpose of this study was to determine the relationship between exclusive breastfeeding and language development of children aged 12-36 months in the Work Area of Makassar Tamamaung Health Center. The research design used was an analytic survey with a cross sectional study approach. This study uses purposive sampling with a sample size of 40 respondents. Relationship test was conducted using Chi-Square statistical test with a significance level of $\alpha=<0.05$. The results showed that there was a relationship between exclusive breastfeeding and children's language development in the work area of the Tamamaung Makassar Public Health Center $(\rho=0.021)$. Based on the results of the study, it showed that there was a relationship between exclusive breastfeeding and the development of children's language in the Tamamaung Makassar Health Center Work Area. For this reason, it is suggested to the relevant parties to provide intensive counseling to mothers, especially to young mothers who have children about the importance of exclusive breastfeeding for child growth and development.
\end{abstract}

Keywords: ASI, Language Development, Toddler. 


\section{PENDAHULUAN}

Perkembangan yang dialami seorang anak merupakan rangkaian perubahan secara teratur dari satu tahap perkembangan ke tahap perkembangan berikutnya, dan berlaku secara umum, misal : anak berdiri dengan satu kaki, berjingkat, (berjinjit) jalan, menaiki tangga, berlari dan seterusnya sedangkan pertumbuhan dapat meliputi perubahan fisik, berpikir, berperasaan, bertingkah laku dan lain-lain (Triyani dkk, 2014). Salah satu manfaat ASI adalah mempengaruhi pertumbuhan dan perkembangan bayi yang terus meningkat jika diberi ASI selama 6 bulan (Kemenkes, 2014)

WHO \& UNICEF membuat deklarasi yang dikenal dengan deklarsi innocenti (Innocenti Declaration). Deklarasi ini bertujuan untuk mempromosikan dan memberikan dukungan pada pemberian ASI. Deklarasi ini didasarkan pada bukti ilmiah tentang manfaat ASI pada daya tahan tubuh bayi, pertumbuhan dan perkembangannya.

ASI Eksklusif juga sudah diatur oleh Negara Indonesia yaitu pada Pasal 128 UU No. 36 Tahun 2009 tentang Kesehatan (UU Kesehatan) mengenai pemberian air susu ibu (ASI) eksklusif. Peraturan ini menjadi salah satu solusi untuk meningkatkan status gizi balita, karena akan meningkatkan kecakupan ASI eksklusif.

Provinsi Sulawesi Selatan juga mengeluarkan Perda No 6 Tahun 2010 tentang ASI eksklusif dalam upaya peningkatan pemberian ASI eksklusif, mengurangi gencarnya promosi susu formula serta meningkatkan respons terhadap ASI eksklusif. Selain itu, alasan dikeluarkanya Perda ini adalah adanya fakta yang menunjukkan pemberian ASI eksklusif belum maksimal sehingga meningkatkan angka gizi buruk pada bayi yaitu belum mencapai angka di bawah 5 persen, yang nantinya akan berdampak terhadap sumber daya manusia yang kurang baik.

Persentase pemberian ASI eksklusif di daerah Provinsi Sulawesi Selatan dari tahun 2008 hingga tahun 2012 mengalami peningkatan dan penurunan. Pada tahun 2008 cakupan pemberian ASI eksklusif cukup tinggi yaitu 77,18\%. Di tahun 2009 cakupan pemberian ASI eksklusif menurun menjadi 59,80\%. Selanjutnya pada tahun 2010 cakupan kunjungan bayi meningkat menjadi $78,45 \%$, dan cakupan ASI eksklusif meningkat menjadi 67,58\%. Di tahun 2011 cakupan ASI eksklusif mengalami penurunan menjadi 41,32\%. Dan kembali meningkat pada tahun 2012 yaitu 53,33\% (Dinkes Kota Makassar, 2013).

Selain Peraturan Pemerintah Sulawesi Selatan, upaya peningkatan pemberian ASI eksklusif juga diatur dalam peraturan Walikota Makassar No. 49 Tahun 2012. Persentase pemberian ASI eksklusif pada bayi 0-6 bulan di wilayah Puskesmas se-Kota Makassar tahun 2011 36,8\%, meningkat di tahun 2012 sebesar $63,7 \%$ dan pada tahun 2013 67,8\%. Peningkatan pemberian ASI eksklusif di Kota Makassar ini sesuai dengan harapan Pemerintah Kota Makassar. Penelitian Profil Kesehatan Makassar (Dinas Kesehatan, 2014) Adanya peraturan untuk pemberian ASI eksklusif ini di dasarkan pada hasil penelitian ilmiah tentang manfaat ASI. Dari data yang diperoleh di Puskesmas Tamamaung jumlah ibu yang mempunyai anak yang berkunjung pada bulan Desember, Januari-Februari 2018 adalah sebanyak 67 orang yang memberikan ASI eksklusif adalah sebanyak 24 orang sedangkan yang tidak memberikan ASI eksklusif sebanyak 43 orang. Selain itu juga di dapatkan data dari hasil pengamatan perkembangan bayi dari 67 anak sebanyak $30 \%$ mengalami keterlambatan perkembangan bahasa. Dengan mengamati keadaan tersebut peneliti tertarik untuk mengetahui "hubungan antara pemberian ASI eksklusif dengan perkembangan bahasa anak usia 12-36 bulan di Puskesmas Tamamaung Kota Makassar".

\section{METODE}

Desain penelitian yang digunakan yaitu penelitian kuantitatif. Penelitian ini menggunakan Survei Analitik dengan pendekatan cross sectional study dimana dalam hal ini dimaksudkan untuk mengetahui hubungan antara pemberian ASI eksklusif (Variabel Independen), dengan perkembangan bahasa anak usia 12-36 bulan (Variabel Dependen) di Puskesmas Tamamaung Kota Makassar. Sampel dalam penelitian ini 40 responden. Analisis data pada penelitian yaitu univariat dan bivariat. Instrumen yang digunakan yaitu kuesioner dan lembar DDST (Denver Development Screening Test).

\section{HASIL}

Penelitian ini dilakukan untuk mengetahui hubungan antara pemberian ASI eksklusif dengan perkembangan bahasa anak usia 12-36 
bulan di Puskesmas Tamamaung Makassar, yang dilaksanakan dari tgl 8 April - 8 Mei 2018. Jumlah sampel yang di dapatkan dalam penelitian di wilayah Puskesmas Tamamaung Makassar sebanyak 40 responden.

Tabel 1 Distribusi Responden Berdasarkan Pemberian ASI di Wilayah Kerja Puskesmas Tamamaung Makassar

\begin{tabular}{|c|c|c|}
\hline \multirow{2}{*}{ Pemberian ASI } & \multicolumn{2}{|c|}{ Jumlah } \\
\cline { 2 - 3 } & N & $\%$ \\
\hline Eksklusif & 25 & 62,5 \\
Non Eksklusif & 15 & 37,5 \\
\hline Total & 40 & 100 \\
\hline
\end{tabular}

Tabel 2 Distribusi Responden berdasarkan Perkembangan Bahasa Anak di Wilayah Kerja Puskesmas Tamamaung Makassar

\begin{tabular}{|c|c|c|}
\hline \multirow{2}{*}{ Perkembangan } & \multicolumn{2}{|c|}{ Jumlah } \\
\cline { 2 - 3 } Bahasa Anak & $\mathrm{N}$ & $\%$ \\
\hline Normal & 34 & 85,0 \\
Tidak Normal & 6 & 15,0 \\
\hline Total & 40 & 100 \\
\hline
\end{tabular}

Tabel 3 Hubungan Antara Pemberian ASI Eksklusif Dengan Perkembangan Bahasa Anak Di Wilayah Kerja Puskesmas Tamamaung Makassar

\begin{tabular}{|c|c|c|c|c|c|c|c|}
\hline \multirow{3}{*}{$\begin{array}{c}\text { Pemberian } \\
\text { ASI }\end{array}$} & \multicolumn{4}{|c|}{ Perkembangan Bahasa } & \multirow{2}{*}{\multicolumn{2}{|c|}{$\begin{array}{c}\text { Total } \\
(\%)\end{array}$}} & \multirow{3}{*}{$\rho$} \\
\hline & \multicolumn{2}{|c|}{ Normal } & \multicolumn{2}{|c|}{$\begin{array}{c}\text { Tidak } \\
\text { Normal }\end{array}$} & & & \\
\hline & $\mathrm{n}$ & $\%$ & $\mathrm{n}$ & $\%$ & $\mathrm{n}$ & $\%$ & \\
\hline $\begin{array}{l}\text { Eksklusif } \\
\text { Non }\end{array}$ & 24 & 70,6 & 1 & 16,7 & 25 & 62,5 & 0,021 \\
\hline Eksklusif & 10 & 29,4 & 5 & 83,3 & 15 & 37,5 & \\
\hline Total & 34 & 100 & 6 & 100 & 40 & 100 & \\
\hline
\end{tabular}

Tabel 1 menunjukkan bahwa distribusi frekuensi responden berdasarkan pemberian ASI terbanyak yaitu pemberian ASI eksklusif sebanyak $62,5 \%$, sedangkan pemberian ASI non eksklusif sebanyak $37,5 \%$.

Berdasarkan tabel 2 menunjukkan bahwa distribusi frekuensi responden berdasarkan perkembangan bahasa anak yang normal sebanyak $85,0 \%$ sedangkan, kategori perkembangan bahasa anak yang tidak normal sebanyak $15,0 \%$.

Melalui Tabel 3 tentang hubungan antara pemberian ASI eksklusif dengan perkembangan bahasa anak usia 12-36 bulan di Puskesmas Tamamaung Makassar menunjukkan bahwa dari 40 anak terlihat bahwa anak yang diberikan ASI eksklusif pada perkembangan bahasa anak dengan kategori normal sebanyak $70,6 \%$ pada kategori perkembangan bahasa anak tidak normal yaitu sebanyak $16,7 \%$. Sementara pada pemberian ASI non Eksklusif perkembangan bahasa anak dengan kategori normal yaitu sebanyak 29,4\% dan untuk perkembangan bahasa tidak normal sebanyak $83,3 \%$. Berdasarkan hasil penelitian analisa statistik uji Chi-Square didapatkan hasil $\rho=0,021$ atau $\rho<0,05$ yang artinya ada hubungan antara pemberian ASI eksklusif dengan perkembangan bahasa anak.

\section{PEMBAHASAN}

Pemberian Asi Eksklusif Pada Anak Usia 12-36 Bulan Di Puskesmas Tamamaung Makassar.

Berdasarkan hasil penelitian dengan mengambil jumlah sampel keseluruhan anak dengan pemberian ASI eksklusif di Puskesmas Tamamaung Makassar didapatkan hasil bahwa pemberian ASI eksklusif lebih banyak dibandingkan dengan anak yang tidak diberikan ASI eksklusif. Dimana anak dengan pemberian ASI eksklusif sebanyak 62,5\% hal ini disebabkan karena beberapa faktor salah satunya yaitu faktor pendorong ibu memberikan ASI eksklusif karena banyaknya informasi tentang pemberian ASI eksklusif yang didapatkan ibu dari tenaga kesehatan baik di Puskesmas maupun di Rumah Sakit sehingga pengetahuan ibu semakin meningkat dan diterapkannya melalui pemberian ASI eksklusif untuk anaknya. Sedangkan anak yang tidak diberikan ASI eksklusif sebanyak 37,5\% hal ini disebabkan karena ibu yang bekerja biasanya mempunyai kesibukan diluar rumah, dimana tingkat pendidikan merupakan salah satu aspek sosial yang umumnya berpengaruh pada tingkat pendapatan keluarga sebagai faktor ekonomi. Pendidikan juga dapat mempengaruhi sikap dan tingkah laku manusia. Semakin tinggi tingkat pendidikan ibu, semakin tinggi jumlah ibu tidak memberikan ASI pada bayinya. Hal ini mungkin disebabkan karena ibu berpendidikan tinggi biasanya mempunyai banyak kesibukan diluar rumah, sehingga cenderung meninggalkan bayinya. Sedangkan ibu berpendidikan rendah lebih banyak 
mempunyai kesempatan untuk menyusui bayinya.

Hasil uji Chi-Square menunjukkan bahwa terdapat hubungan antara pekerjaan ibu dengan pemberian ASI eksklusif. Hasil penelitian dilapangan menunjukkan bahwa ibu yang bekerja maupun tidak bekerja cenderung tidak memberikan ASI eksklusif. Dalam hal ini mungkin yang mempengaruhi adalah tingkat pengetahuan ibu tentang ASI eksklusif.

Hal ini sejalan dengan penelitian yang dilakukan oleh Nirwana (2014) di Medan dimana ada hubungan antara pekerjaan ibu dengan pemberian ASI eksklusif. ${ }^{7}$ Bagi ibu yang bekerja, upaya pemberian ASI eksklusif seringkali mengalami hambatan lantaran singkatnya masa cuti hamil dan melahirkan. Sebelum pemberian ASI eksklusif berakhir secara sempurna, dia harus kembali bekerja. Kegiatan atau pekerjaan ibu sering kali dijadikan alasan untuk tidak memberikan ASI ekskklusif terutama yang tinggal di perkotaan (Zakiyah, 2012).

Seminar yang memperingati Pekan ASI Sedunia tahun 2008 mengemukakan bahwa banyak faktor yang menjadi masalah rendahnya pemberian ASI di Indonesia, salah satunya yaitu dukungan suami yang merupakan orang terdekat sebagai kunci selama kehamilan, persalinan dan setelah bayi dilahirkan termasuk pemberian ASI. Dukungan suami akan mempengaruhi kondisi psikologis ibu karena suami merupakan faktor pendukung pada kegiatan yang bersifat emosional dan psikologis. Sekitar $80 \%-90 \%$ produksi ASI ditentukan oleh keadaan emosi ibu yang berkaitan dengan refleks oksitosin ibu berupa pikiran, perasaan dan sensasi. Dukungan suami membuat ibu berpeluang untuk memberikan ASI eksklusif dari pada yang tidak didukung suami (Triyani dkk,2014).

Beberapa faktor penghambat pemberian ASI eksklusif antara lain adalah bayi berusia dibawah 6 bulan sudah diberikan makanan ataupun minuman lain yang seharusnya hal tersebut diberikan sebagai makanan pendamping air susu ibu (MPASI) pada bayi berusia diatas 6 bulan. Selain itu juga dipengaruhi oleh maraknya promosi susu formula di berbagai media dan fasilitas kesehatan, kurangnya pengetahuan ibu tentang kandungan nutrisi ASI, kurangnya pengetahuan ibu tentang kebutuhan gizi bayi berusia 0-6 bulan. Anak berusia 6-24 bulan tidak lagi hanya diberikan ASI saja tetapi harus ditambah dengan pemberian makanan pendamping air susu ibu (MPASI) hal ini dikarenakan kandungan nutrisi dalam ASI tidak lagi dapat memenuhi kebutuhan nutrisi anak pada usia 6-24 bulan sehingga harus ditambah dengan pemberian MPASI (Andiany dkk, 2013).

Adapun Perbedaan berat badan bayi yang diberikan ASI eksklusif dengan bayi yang diberikan makanan pendamping ASI. Bayi yang diberi ASI eksklusif memiliki berat badan normal, sedangkan sebagian bayi yang diberikan makanan pendamping ASI mengalami kegemukan (obesitas). Bayi yang diberikan ASI eksklusif secara keseluruhan memilki status gizi yang normal, dalam hal ini berat badannya tergolong normal tidak ada yang mengalami obesitas maupun kurang gizi. ASI merupakan makanan utama dan terbaik yang dapat memenuhi kebutuhan gizi bayi baru lahir sampai usia 6 bulan. Kandungan ASI antara lain adalah zat kekebalan tubuh, anti infeksi, serta semua nutrisi yang memang dibutuhkan oleh bayi baru lahir sampai berusia 6 bulan. Bayi yang diberi ASI eksklusif selama 6 bulan memiliki tumbuh kembang yang optimal (normal), sehingga kejadian obesitas pasti dapat dicegah, karena ASI dapat mengontrol berat badan bayi. Pada dasarnya, pelaksanaan pemberian ASI eksklusif selama 6 bulan dan pemberian MPASI pada bayi berusia 6-24 bulan bertujuan untuk mencapai status gizi balita yang baik. Penilaian status gizi yang baik dilakukan melalui kegiatan penimbangan berat badan anak setiap bulan yang biasanya dilakukan di Posyandu maupun fasilitas kesehatan lainnya. Jika setiap bulan anak mengalami berat badan sesuai dengan standar grafik yang tercantum dalam buku Kesehatan Ibu dan Anak (KIA) dari kementrian kesehatan, maka dapat disimpulkan bahwa anak tersebut memilki status gizi yang baik (Bahriyah dkk, 2017).

\section{Status Perkembangan Bahasa Anak Usia 12-36 Bulan Di Puskesmas Tamamaung Makassar.}

Berdasarkan hasil penelitian dengan mengambil jumlah sampel keseluruhan anak yang mengalami perkembangan bahasa di Puskesmas Tamamaung Makassar didapatkan hasil bahwa perkembangan bahasa normal 
mendapat jumlah lebih banyak dibandingkan dengan perkembangan bahasa tidak normal.

Dimana anak dengan perkembangan bahasa normal sebanyak 85,0\%, sedangkan anak dengan perkembangan bahasa tidak normal sebanyak $15,0 \%$. Hal ini disebabkan karena anak yang diberikan ASI eksklusif lebih baik perkembangan bahasanya dibandingkan dengan anak yang tidak diberikan ASI eksklusif. Rata-rata anak yang diberikan ASI eksklusif dapat melakukan uji coba tes perkembangan dengan menggunakan DDST anak mampu mengikuti tes uji coba yang terletak di kanan garis umur, sedangkan anak yang tidak diberikan ASI eksklusif sebagian besar mengalami keterlambatan dalam melakukan uji coba tes perkembangan bahasa.

Hasil uji Chi-Square menunjukkan bahwa terdapat hubungan antara pemberian ASI eksklusif dengan perkembangan bahasa anak. Hasil penelitian di lapangan menunjukkan bahwa anak yang diberikan ASI eksklusif mampu melakukan tugas perkembangan dibandingkan dengan anak yang tidak diberikan ASI eksklusif.

Hal ini sejalan dengan Ida (2012), menyatakan bahwa perkembangan dan pertumbuhan akan terus berkembang hingga dewasa dalam proses tumbuh kembang sangat dipengaruhi oleh makanan yang diberikan kepada anak. Makanan yang sangat sesuai bagi anak adalah ASI karena ASI diperuntukkan bagi anak sebagai makanan pokok. Anak dapat mencapai pertumbuhan optimal apabila diberikan ASI eksklusif sampai usia 4-6 bulan, dan setelah itu tetap diberikan sampai usia 2 tahun dengan diberi tambahan makanan pendamping ASI (Roesli, 2014).

\section{Hubungan Antara Pemberian Asi Eksklusif Dengan Perkembangan Bahasa Anak Usia 12-36 Bulan Di Puskesmas Tamamaung Makassar.}

Hasil uji statistik Chi-Scuare didapatkan nilai $\rho$ $=0,021(\rho<0,05)$. Sehingga dapat disimpulkan bahwa hasil penelitian ini menunjukkan terdapat hubungan pemberian ASI eksklusif dengan perkembangan bahasa anak usia 12-36 bulan di Puskesmas Tamamaung Makassar.

Berdasarkan hasil penelitian dengan mengambil jumlah sampel keseluruhan anak yang diberikan ASI eksklusif di Puskesmas Tamamaung Makassar didapatkan hasil bahwa pemberian ASI eksklusif mendapat jumlah lebih banyak dibandingkan dengan anak yang tidak diberikan ASI eksklusif. Dimana anak dengan pemberian ASI eksklusif menyebabkan perkembangan bahasa normal sebanyak 70,6\% sedangkan anak dengan pemberian ASI non eksklusif didapatkan perkembangan bahasa tidak normal sebanyak 83,3\%.

Faktor terpenting dalam proses tumbuh kembang termasuk pertumbuhan otak adalah nutrisi yan $g$ diberikan. Faktor-faktor yang mempengaruhi kuantitas dan kualitas nutrisi secara langsung juga dapat mempengaruhi pertumbuhan otak. Memberikan ASI secara eksklusif sampai bayi berusia 6 bulan akan menjamin tercapainya pengembangan potensi kecerdasan anak secara optimal (Roesli, 2014). Hal ini sesuai dengan penelitian yang dilakukan oleh Kamsiah (2015), bahwa anak yang diberikan ASI eksklusif memiliki perkembangan yang lebih baik dibandingkan dengan anak yang tidak diberikan ASI eksklusif, khususnya pada perkembangan bahasa anak. Pada penelitian ini menunjukkan bahwa pemberian ASI eksklusif dapat mempengaruhi perkembangan bayi usia 7-12 bulan. Pemberian makanan pendamping ASI (MP-ASI) dini merupakan salah satu penyebab terjadinya gangguan perkembangan bayi.

Hasil penelitian ini tidak sesuai dengan penelitian yang dilakukan oleh Mumin (2013), yang dimana tidak ada hubungan pemberian ASI Eksklusif terhadap perkembangan usia toodler disebabkan karena banyak faktor lain yang menyebabkan tidak adanya hubungan pemberian ASI terhadap perkembangan bahasa anak usia toodler seperti terhambatnya kebutuhan stimulasi anak, asupan gizi yang kurang dan pemberdayaan keluarga yang memiliki makna bagaimana keluarga memampukan dirinya sendiri dengan difasilitasi orang lain untuk meningktakan atau mengontrol status kesehatan keluarga.

Hasil penelitian ini sesuai dengan penelitian Deoni, dkk (2013), di kelurahan Semanam Kecamatan Kali Deres Jakarta Barat dan penelitian ini sejalan dengan penelitian Ida (2012), bahwa ada hubungan antara pemberian ASI dengan perkembangan bahasa anak karena kandungan gizi yang terkandung dalam ASI seperti Taurin dan Long hain Poyunsaturated Fatty yang sangat berguna bagi penglihatan dan perkembangan bahasa anak, dan zat gizi ini hanya terdapat dalam ASI saja, sedangkan 
laktosa dan asam lemak ikatan panjang hanya sedikit terkandung adalah susu formula (Mumin, 2013).

Berdasarkan hal tersebut peneliti berasumsi bahwa pemberian ASI eksklusif terhadap anak dapat mempengaruhi perkembangan bahasa anak. Karena anak yang diberikan ASI ekslusif dapat mempengaruhi pertumbuhan otak dan juga menjamin tercapainya pengembangan potensi kecerdasan anak secara optimal. Dan anak yang diberikan ASI eksklusif memiliki perkembangan bahasa yang lebih baik dibandingkan dengan anak yang tidak diberikan ASI eksklusif.

\section{KESIMPULAN}

Kesimpulan penelitian ini yaitu ada hubungan antara pemberian ASI eksklusif dengan perkembangan bahasa anak usia 12-36 bulan di Puskesmas Tamamaung Kelurahan Tamamaung Kecamatan Panakukang Makassar dengan nilai $\rho=0,021$.

\section{REFERENSI}

1. Andiyani, E dkk. Perbedaan Pertumbuhan Berat Badan Bayi ASI Eksklusif dan Non Eksklusif di Wilayah Kerja Puskesmas Peuka badan Kabupaten Aceh Besar. Banda Aceh: Idea Nursing Jurnal Volume IV No. 2 tahun 2013; 47-52

2. Bahriyah, F dkk. Hubungan Pekerjaan Ibu Terhadap Pemberian ASI Eksklusif Pada Bayi. Riau ; Jurnal Edurance Vol 2 No 2 Juni Tahun 2017 ; 113-118.

3. Deoni, S. C. Dkk. 2013. Breastfeeding and early white matter development: A crosssectional study. Journal of NeuroImage $82: 77-86$.

4. Dinas Kesehatan. 2013. . Profil kesehatan Provinsi Sulawesi Selatan Kota Makassar

5. Dinas Kesehatan. 2014. Profil Kesehatan Kota Makassar. Makassar

6. Ida. 2012. Faktor-Faktor yang Berhubungan dengan Pemberian ASI Eksklusif 6 Bulan. Di Wilayah Kerja
Puskesmas Kemiri Muka Kota. Depok: FKM UI

7. Kamsiah.2015. Hubungan ASI Eksklusif dengan Perkembangan Bayi di Wilayah Kerja Puskesmas Jalan Gedang Kecamatan Gading Cempaka Kota Bengkulu. Tesis. Program Pasca Sarjana Fakultas Kedokteran Universitas Gadjah Mada Yogyakarta.

8. Kemenkes. 2015. Profil Kesehatan Indonesia Jakarta: Kementrian kesehatan Republik Indonesia.

9. Maryunani, A. 2012. Inisiasi Menyusui Dini, ASI Eksklusif, dan Manajemen Laktasi. Jakarta: CV. Trans Info Media.

10.Mumin. 2013. Faktor-Faktor yang berhubungan dengan Pemberian ASI Eksklusif di Puskemsmas Tamamaung. Skripsi Tidak Dipublikasihkan, Makassar: Unuversitas Muslim Indonesia makassar.

11.Nirwana, A. B. 2014. ASI dan Susu Formula.

12.Roesli, Utami. 2014. ASI Panduan Praktis Ibu Menyusui. Yogyakarta : Banyu Media

13.Triyani, S., Meilan, N., \& Purbowati, N. 2014. Hubungan antara lama Pemberian ASI Eksklusif dengan Perkembangan Anak Usia 12-36 Bulan. Jurnal Internasional; 114.

14.Zakiyah. 2012. Faktor-Faktor yang Berhubungan Dengan Pemberian ASI Eksklusif. Di Kelurahan Semenan Kecamatan Kalideres Jakarta Barat. Depok: FKM UI. 